\title{
Our Early Results of Isolated Coronary Artery Bypass Grafting: A Case Series of the First 100 Patients in a Newly Established Heart Center
}

\author{
Izole Koroner Bypas Greftleme Erken Dönem Sonuçlarımız: \\ Yeni Kurulan Bir Kalp Merkezi Ilk 100 Vaka
}

\author{
Ebuzer AYDIN $\odot$, Mehmet Senel BADEMCI $\odot$, Cemal KOCAASLAN $\odot$, Emine Seyma DENLI YALVAC $\bullet$, \\ Ahmet OZTEKIN $\odot$, Mustafa ALDAG $\odot$, Senem KORUK $\odot$
}

Ethics Committee Approval: This study approved by the Istanbul Medeniyet University, Goztepe Training and Research Hospital Clinical Studies Ethic Committee, 28 November 2018, 2018/0397. Conflict of interest: The authors declare that they have no conflict of interest.

Funding: None.

Informed Consent: Not Applicable.
Cite as: Aydin E, Bademci MS, Kocaaslan C, et al. Our Early Results of Isolated Coronary Artery Bypass Grafting: A Case Series of the First 100 Patients in a Newly Established Heart Center. Medeniyet Med J. 2019;34:188-93.

\begin{abstract}
Objective: In this study, we aimed to investigate the early results of the first 100 patients who underwent isolated elective coronary artery by-pass surgery because of coronary artery disease in our clinic.

Methods: The first 100 patients who underwent isolated elective coronary artery by-pass surgery between October 2016-January 2018 were included. In the study routine blood tests, echocardiography, electrocardiography, chest X-ray, carotid-vertebral artery doppler ultrasound, pulmonary function tests were performed and nasal culture was obtained preoperatively. Euroscore II scoring system was used for calculating the mortality risk. All operations were performed under intrathoracic general anesthesia. Using median sternotomy approach, ascending aortic cannulation, unicaval venous cannulation, intermittent antegrade cold blood cardioplegia and under mild hypothermia cardiopulmonary by-pass were performed.

Results: Median age was 58 years and 35\% $(n=35)$ of the patients were female. Most common preoperative risk factors were hypertension (HT) (50\%; $n=50)$ and smoking (42\%; $n=42)$. Mean cardiopulmonary by-pass time was $70 \pm 13$ minutes, mean cross-clamp time was $40 \pm 16$ minutes, mean number of revascularized coronary arteries was 3.4 \pm 1.0. Postoperative atrial fibrillation was detected in $22 \%(n=22)$ of the patients, and all patients were converted to sinüs ritm with medical treatments. In hospital mortality was $2 \%(n=2)$.

Conclusion: Surgical treatment of isolated coronary artery disease, especially in low-risk patient group, remains in the current treatment guidelines with low mortality and morbidity rates.
\end{abstract}

Keywords: Early results, isolated, elective coronary artery by-pass surgery

ÖZ

Amaç: Bu çalışmada, yeni kurulan kalp ve damar cerrahisi kliniğimizde koroner arter hastalığı nedeniyle, izole elektif koroner arter bypas ameliyatı olan ilk 100 vakanın erken dönem sonuçlarının değerlendirilmesini amaçladık.

Yöntem: Ekim 2016 ile Ocak 2018 tarihleri arasında izole elektif koroner arter bypas ameliyatı olan ilk 100 hasta çalışmaya dahil edildi. Preoperatif dönemde tüm hastalara; rutin kan tetkikleri, ekokardiyografi, elektrokardiyografi, akciğer grafisi, karotis-vertebral arter Doppler ultrasonografi, solunum fonksiyon testi yapıldı ve burun kültürleri alındı. Mortalite riskinin hesaplanması için Euroscore II skorlama sistemi kullanıldı. Operasyon intratorasik genel anestezi altında, median sternotomi insizyon tekniği ile asendan aorta arteriel kanülasyon, unikaval venöz kanülasyon essliğinde, aralıklı antegrad soğuk kan kardiyoplejisi ve hafif hipotermiyle kardiyopulmoner bypas altında yapıldı. Taburculuk sonrası 2. -4. hafta ve 2. ay poliklinik kontrol muayeneleri yapıldı. Hastaların verileri retrospektif olarak tarandı.

Bulgular: Ortalama yașı 58 yıl olup, hastaların \%35 $(n=35)$ 'i kadın cinsiyet idi. En sık görülen risk faktörleri; \%50 ( $n=50)$ 'sinde hipertansiyon (HT), \%42 (n=42)'sinde sigara içme öyküsü idi. Operasyonda ortalama CPB süresi $70 \pm 13$ dk., ortalama kross klemp zamanı $40 \pm 16$ dk., ortalama bypas yapılan damar sayısı 3.4 1.0 idi. Postoperatif dönemde $\% 22(n=22)$ hastada atriyal fibrilasyon gelişti ve tüm hastalarda medikal tedavi ile sinüs ritmi sağlandı. Hastane içi mortalite \%2 $(n=2)$ hastada görüldü.

Sonuc: Izole koroner arter hastalığının cerrahi tedavisi, özellikle düşük riskli hasta grubunda, düşük mortalite ve morbidite oranları olan güncel tedavideki yerini korumaktadir.

Anahtar kelimeler: Erken sonuçlar, izole, elektif koroner arter bypas cerrahisi
Received: 23.01.2019

Accepted: 05.03.2019

Online First: 10.06 .2019

Corresponding Author: E. Aydin ORCID: 0000-0002-9822-0022 Istanbul Medeniyet University Medical Faculty, Department of Cardiovascular Surgery, Istanbul - Turkey

drebuzeraydin@gmail.com

M.S. Bademci

ORCID: 0000-0001-9442-889X

C. Kocaaslan

ORCID: 0000-0002-1348-2411 E.S. Denli Yalvac

ORCID: 0000-0003-0629-660X

A. Oztekin

ORCID: 0000-0001-8284-6656

M. Aldag

ORCID: 0000-0003-1363-4267

Istanbul Medeniyet University

Medical Faculty, Department of Cardiovascular Surgery, Istanbul, Turkey

S. Koruk

ORCID: 0000-0003-1795-150X

Istanbul Medeniyet University Medical Faculty, Department of Anesthesiology, Istanbul, Turkey 


\section{INTRODUCTION}

Cardiovascular diseases are the leading causes of death worldwide due to sedentary lifestyle, irregular and unhealthy eating habits, and increased urbanization and aging of the population. In particular, mortality related to coronary artery disease (CAD) has been increasingly reported in the 35 to 55 age group ${ }^{1}$.

The first coronary artery bypass grafting (CABG) was performed in Turkey in $1960^{2}$. Later on, the number of heart surgery centers has increased. Our healthcare institute was established in 1972. In 2016, heart surgery clinic in addition to vascular surgery was established and the first open heart surgery was successfully performed on the date of $12^{\text {th }}$ October, 2016.

In this study, we present our early results of isolated $C A B G$ in a series of the first 100 patients in our newly established heart center.

\section{MATERIAL and METHODS}

This study approved by the Istanbul Medeniyet University, Goztepe Training and Research Hospital Clinical Studies Ethic Committee, 28 November 2018, 2018/0397.

Between October 2016 and January 2018, a total of 100 patients aged between 42 and 80 years who underwent elective, isolated $C A B G$ due to CAD under cardiopulmonary bypass (CPB) were included in the study. Patients who underwent emergency CABG or another cardiac surgery were excluded from the study. Pre, and postoperative data were retrieved from the medical files of the patients using the hospital database and were retrospectively analyzed. All patients were informed about the nature of the procedure and a written informed consent was obtained one day prior to surgery.

In the preoperative period, all patients underwent routine biochemistry tests, echocardiography, electrocardiography, thoracic X-ray, doppler imaging of the carotid and vertebral arteries, pulmonary function tests, and nasal culture for staphylococcus aureus carriage. The patients with critical carotid stenosis as evidenced by doppler imaging of the carotid artery were scheduled for angiography. Erythrocyte suspension, fresh frozen plasma, and platelet suspension were prepared for blood transfusion. The EuroSCORE II scoring system was used to identify the risk of perioperative mortality. Accordingly, scores of $\leq 3,4-6$, and $\geq 7$ points indicate low, intermediate, and high risk, respectively. All patients were preoperatively consulted to an anesthesiologist. The patients were given premedication on the night before surgery. The patients were operated under antiaggregant therapy (i.e., acetylsalicylic acid $100 \mathrm{mg}$ ).

All patients were operated under intrathoracic general anesthesia using a median sternotomy incision. A transesophageal echocardiography probe was placed for monitoring postoperative intracardiac deairing and ventricular functions. A cerebral pulse oximeter was used to monitor cerebral perfusion. Following induction of anesthesia, tranexamic acid $(12 \mathrm{mg} / \mathrm{kg})$ was administered, until CPB was initiated. Heparin (300-400 U/ $\mathrm{kg}$ ) was given for a target-activated clotting time (ACT) of 450 to $700 \mathrm{sec}$. All operations were done under CPB through arterial cannulation of the ascending aorta and unicaval venous cannulation using intermittent cold antegrade blood cardioplegia and mild hypothermia $\left(30^{\circ} \mathrm{C}-32^{\circ} \mathrm{C}\right)$. The left internal mammary artery was used to access into the left anterior descending coronary artery, while an appropriate saphenous vein graft was used for other coronary arteries. After distal coronary anastomosis were completed, the cross-clamp was removed and proximal anastomosis were performed using side clamps. Distal anastomosis were done using $7 / 0$ prolene sutures, while proximal anastomosis were done using $6 / 0$ prolene sutures through end-to-side anastomosis techni- 
que. Neutralization of heparin was achieved with protamine using 1.3 times higher doses than the heparin dose applied. All patients were transferred to the intensive care unit (ICU) postoperatively and followed for two days. Drains and urinary catheters were removed in the patients who were hemodynamically stable, and these patients were transferred to the surgical ward. The patients who had an uneventful course during hospitalization were discharged on postoperative day 7 with full recovery. The patients were scheduled for followup visits in the outpatient setting at two, four, and eight weeks after their discharge.

\section{Statistical Analysis}

Statistical analysis was performed using the Statistical Package for the Social Sciences (SPSS) for Windows version (SPSS15.0 Inc., Chicago, IL, USA). Descriptive data were expressed in mean and standard deviation (SD), while categorical data were expressed in number and frequency.

\section{RESULTS}

Sixty-five study patients (65\%) were male and 35 $(35 \%)$ of them were female with an overall mean

Table 1. Baseline demographic and clinical characteristics of patients.

\begin{tabular}{ll}
\hline Variable & $\begin{array}{l}\text { Study population } \\
(\mathbf{n}=\mathbf{1 0 0})\end{array}$ \\
\hline Sex (F/M), n (\%) & $35(35) / 65(65)$ \\
Age, years (range) & $58(42-80)$ \\
DM, n (\%) & $35(35)$ \\
HT, n (\%) & $50(50)$ \\
Smoking history, n (\%) & $42(42)$ \\
COPD, n (\%) & $26(26)$ \\
Renal impairment, n (\%) & $3(3)$ \\
Previous cerebrovascular event, n (\%) & $2(2)$ \\
PAD, n (\%) & $4(4)$ \\
Previous MI, n (\%) & $38(38)$ \\
BL EF, \% (min-max) & $60(45-65)$ \\
EuroSCORE II, n (\%) & $20(20)$ \\
$\quad$ Low risk & $55(55)$ \\
Intermediate risk & $25(25)$ \\
High risk & $20(20)$ \\
\end{tabular}

DM; diabetes mellitus, HT; hypertension, COPD; chronic obstructive pulmonary disease, PAD; peripheral artery disease, MI; myocardial infarction, $B L$; baseline, EF; ejection fraction. age of 58 (range, 42 to 80 ) years. Respective number of patients had $(n=35: 35 \%)$ diabetes mellitus (DM), hypertension ( $\mathrm{n}=50$ : $50 \%)$, a smoking history ( $n=42: 42 \%)$, chronic obstructive pulmonary disease (COPD: $n=26: 26 \%)$, renal dysfunction not requiring dialysis $(n=3: 3 \%)$, previous cerebrovascular event, $(n=2: 2 \%)$, peripheral artery disease (without resting pain or limb ulceration) $(n=4$ : $4 \%)$. In the preoperative period, 38 (38\%) patients had myocardial infarction. According to the EuroSCORE II scoring system, 25 (25\%) patients were in the high-risk group. Baseline demographic and clinical characteristics of the patients are shown in Table 1.

None of the patients with previous cerebrovascular event had a significant carotid artery stenosis requiring intervention. The mean duration of CPB, and cross-clamp were $70 \pm 13 \mathrm{~min}$, and $40 \pm 16 \mathrm{~min}$, respectively, and the mean number of $3.4 \pm 1.0$ vessels were bypassed. An intra-aortic balloon pump was used in three (3\%) patients and inotropic support was given to $12(12 \%)$ patients. During follow-up in the ICU, the mean duration of intubation was $7.2 \pm 3.0 \mathrm{~h}$, the mean amount of drainage was $610 \pm 124 \mathrm{~mL}$, and the mean length of ICU stay was $2.1 \pm 1.0$ days. Packed red blood cells and fresh frozen plasma transfusions were used. The mean per-operative packed red blood cells and fresh frozen plasma transfusions were 2.2 units/patient and 1.5 units/patient, respectively. The mean length of hospital stay was 8.2 days. No intraoperative MI and mortality were seen in any of the patients. However, early mortality ( $\leq 30$ days) was observed in two patients (due to multiple organ failure with COPD-related respiratory and renal failure, $n=1$; due to low cardiac output syndrome, $n=1$ ). In addition, four patients underwent revision surgery in the operating room in the early postoperative period due to hemorrhage during ICU follow-up. In a total of 22 (22\%) patients, postoperative atrial fibrillation which did not lead to hemodynamic instability developed. All these patients returned to sinus rhythm with medical treatment. Two patients (2\%) with 
superficial sternal wound infection were readmitted. Both of them were discharged after medical therapy without surgical revision and any case of mediastinitis was not seen. In two (2\%) patients, reversible right hemiparesis occurred. One of these patients had a history of epilepsy. The intra and postoperative data of the patients are presented in Table 2.

Table 2. Intra and postoperative data.

\begin{tabular}{ll}
\hline Variable & $\begin{array}{l}\text { Study population } \\
(\mathbf{n}=\mathbf{1 0 0})\end{array}$ \\
\hline CPB, min (mean \pm SD) & $70 \pm 13$ \\
Cross-clamping, min (mean \pm SD) & $40 \pm 16$ \\
Number of vessels bypassed, (mean \pm SD) & $3.4 \pm 1$ \\
IABP use, n (\%) & $3(3)$ \\
Inotropic support, n (\%) & $12(12)$ \\
Amount of drainage, mL (mean \pm SD) & $610 \pm 124$ \\
ICU LOS, day (mean \pm SD) & $2.1 \pm 1$ \\
Hospital LOS, day (mean \pm SD) & 8.2 \\
Intubation duration, h (mean $\pm S D)$ & $7.2 \pm 3$ \\
Postoperative AF, n (\%) & $22(22)$ \\
In-hospital mortality, n (\%) & $2(2)$ \\
Estimated in-hospital mortality*, \% & 2.2 \\
Mediastinitis, n (\%) & $0(0)$ \\
Superficial sternal wound infection, $\mathrm{n}(\%)$ & $2(2)$ \\
Revision for bleeding, $\mathrm{n}(\%)$ & $4(4)$ \\
Mean blood product usage, units per patient $2.2 / 1.5$ \\
(red blood/fresh frozen plasma) \\
Postoperative cerebrovascular event, n (\%) $2(2)$ \\
\hline
\end{tabular}

"The EuroSCORE II scoring system was used. SD; standard deviation, CPB; cardiopulmonary bypass, IABP; intra-aortic balloon pump, ICU; intensive care unit, LOS; length of stay, $A F$; atrial fibrillation.

\section{DISCUSSION}

In the beginning of the open heart surgery in our cardiovascular surgery clinic, we encountered several difficulties including limited number of experienced staff and inadequate multidisciplinary teamwork between the cardiovascular surgery and other clinical departments. However, attempts to increase the knowledge and skills of healthcare personnel through clinical training and clinical rotations have yielded successful outcomes. Despite all these difficulties, the mortality and morbidity rates of elective, isolated CABG in our center are consistent with the literature ${ }^{3}$. Increased success rates and credibility have also brought us increased number of patients.

In the present study, we report our early results of isolated $C A B G$ in a series of the first 100 patients in our newly established heart center. Currently, $\mathrm{CABG}$ and percutaneous coronary interventions are recommended by international guidelines for the treatment of $\mathrm{CAD}^{4}$. Although CABG is an effective treatment modality, it is associated with significant postoperative complications. In the early postoperative period, particularly, bleeding, pericardial tamponade, or graft thromboses requiring redo surgery can be seen. Similarly, in our study, four patients experienced early postoperative bleeding and underwent revision surgery. In a study, Lawrence et al. ${ }^{5}$ performed revision surgery due to bleeding in $3.6 \%$ of the patients, consistent with our findings. Although revision surgery due to bleeding in the postoperative period has been associated with increased mortality ${ }^{6}$, we observed no mortality in patients who underwent revision surgery.

In addition, a transient loss of platelet function can be seen after $\mathrm{CABG}$ under $\mathrm{CPB}^{7}$. However, preoperative antiaggregant use, particularly acetylsalicylic acid has not been associated with postoperative bleeding requiring revision surgery with a mortality-reducing effect ${ }^{6}$. Therefore, in our study, all patients were given premedication on the night before surgery and were operated under acetylsalicylic acid treatment.

The early postoperative mortality rates of CABG range between 0.4 to $16 \%$ in the literature ${ }^{8,9}$. There are several risk factors for mortality in this patient population including comorbidities such as DM, COPD, and renal failure or advanced age. Therefore, it is of vital importance to estimate mortality rates before surgery, allowing the surgeon to get prepared for postoperative complications and the patient and his/her relatives to be thoroughly informed about the possible outcomes. For this purpose, EuroSCORE II scoring system is a useful tool 
to assess early mortality and morbidity in patients undergoing isolated CABG with a high success rate $^{10}$. In our study, all patients were evaluated using the EuroSCORE II scoring system preoperatively and the mortality rates were estimated. The in-hospital mortality rate was $2 \%$, consistent with the estimated preoperative mortality rates of 2.2 percent.

Atrial fibrillation is the most common arrhythmia following CABG and has been reported in $40 \%$ of the patients in clinical studies ${ }^{11}$. There are several risk factors for atrial fibrillation including cessation of beta blockers in the preoperative period, postoperative anemia, hypoxia, and CPB-induced inflammatory response. In the present study, postoperative atrial fibrillation was seen in $22 \%$ of the patients and all patients returned to sinus rhythm with medical treatment.

Furthermore, neurological complications of ischemic or hemorrhagic origin due to cerebral hypoperfusion during $\mathrm{CPB}$, underlying carotid artery stenosis, air embolism, and bleeding account for $1.7 \%$ of cases with significant morbidity and mortality ${ }^{12}$. Therefore, it is recommended that patients aged above 70 years or those with the left main coronary artery involvement should be evaluated through Doppler imaging of the carotid artery ${ }^{4}$. In addition, the utilization of a cerebral pulse oximeter is helpful for the surgical team to monitor intraoperative cerebral hypoperfusion ${ }^{13}$. In our clinic, we routinely use this device, as in the case with the present study. In our study, we found reversible cerebrovascular events in two patients and full recovery was able to be achieved with medical treatment before discharge.

Wound infection is another serious complication of surgery ranging from a mild subcutaneous tissue infection to mediastinitis. Although rare, following cardiac surgery, mediastinitis is associated with high mortality ${ }^{14}$. Preventive measures include appropriate sterilization of the surgical field, avoidance of excessive electrocautery use during surgery and use of non-absorbable materials such as bonewax, and meticulous control of bleeding ${ }^{15}$ and use of first generation cephalosporins in the prophylactic treatment. In the present study, we also routinely administered prophylactic antibiotherapy and sternal wound infection limited to the subcutaneous tissue was seen only in two patients, and any case of mediastinitis was not observed.

Nonetheless, there are some limitations of this study. Its single center and retrospective design are the main limitations. In addition, we were able to evaluate only early postoperative results and the mid- and long-term results still remain to be elucidated. Therefore, further large-scale and long-term studies are needed to confirm these findings and to provide additional information to the body of knowledge on this topic.

\section{CONCLUSION}

Isolated coronary artery bypass surgery can be performed successfully under cardiopulmonary bypass with standard technique using intermittent cold antegrade blood cardioplegia with low morbidity and mortality rates even in a newly established cardiovascular surgery clinic.

\section{REFERENCES}

1. Chen W, Gao R, Liu L, et al. China cardiovascular disease report 2014. Chin Circ j. 2015;30:617-22.

2. Köksal C, Sarıkaya S, Özcan V, et al. Open Heart Surgery Experience in SSK Süreyyapaşa Hospital: The First Consecutive 100 Cases. Turk Gogus Kalp Dama. 2002;10:264-6.

3. Muneretto C, Bisleri G, Negri A, et al. Improved graft patency rates and mid-term outcome of diabetic patients undergoing total arterial myocardial revascularization. Heart Int. 2006;2:136. [CrossRef]

4. Neumann FJ, Sousa-Uva M, Ahlsson A, et al. 2018 ESC/ EACTS Guidelines on myocardial revascularization. Kardiol Pol. 2018;76:1585-1664. [CrossRef]

5. Dacey LJ, Munoz JJ, Baribeau YR, et al. Reexploration for hemorrhage following coronary artery bypass grafting: incidence and risk factors. Northern New England Cardiovascular Disease Study Group. Arch Surg. 1998;133:442-7. [CrossRef]

6. Aboul-Hassan SS, Stankowski T, Marczak J, et al. The use of preoperative aspirin in cardiac surgery: A systematic 
review and meta-analysis. J Card Surg. 2017;32:758-74. [CrossRef]

7. Anderson TLG, Solem JO, Tengborn L, Vinge E. Effects of desmopressinn acetate on platelets aggregaiton, Von Willebrand factor, and blood loss after cardiac surgery with extracorporal circulation. Circulation. 1990;81:872-8. [CrossRef]

8. Gurkan S, Gur O, Arar C, Ege T. Yeni Bir Merkez: Adult Kalp Cerrahisinde Illk Altı Ayın Analizi. Turkiye Klinikleri J Cardiovasc Sci. 2012;24:114-8.

9. Kaplan M, Kut MS, Çimen S, Demirtaş MM. EuroSCORE (European System for Cardiac Operative Risk Evaluation) Risk Skorlama Sisteminin Ülkemiz Hasta Profilinde Uygulanabilirliğinin Araştırılması. Turk Gogus Kalp Dama. 2003;11:147-58.

10. Biancari F, Vasques F, Mikkola R, et al. Validation of EuroSCORE II in patients undergoing coronary artery bypass surgery. Ann Thorac Surg. 2012;93:1930-5. [CrossRef]
11. Helgadottir S, Sigurdsson MI, Ingvarsdottir IL, et al. Atrial fibrillation following cardiac surgery: risk analysis and longterm survival. J Cardiothorac Surg. 2012;7:87. [CrossRef]

12. Aldag M, Kocaaslan C, Bademci MS, et al. Consequence of Ischemic Stroke after Coronary Surgery with Cardiopulmonary Bypass According to Stroke Subtypes. Braz J Cardiovasc Surg. 2018;33:462-8. [CrossRef]

13. Kart J, Ulugöl H, Arıtürk C, et al.Evaluation of microcirculation with tissue oxygen saturation monitoring in open heart surgery. Turk Gogus Kalp Dama. 2015;23:651-7. [CrossRef]

14. Yalçınbaş Y, Erek E, Salihoğlu E, et al. Mediastinit Tedavisinde Hemirektus Flebi ve Bilateral Pektoral Kas Kaydırma Tekniği Turk Gogus Kalp Dama. 2002;10:118-9.

15. El Oakley RM, and Wright JE. Postoperative mediastinitis: Classification and management. Ann Thorac Surg. 1996;61:1030-6. [CrossRef] 